УДК 373.3.091.212.2

DOI:

Світлана Лозинська, кандидат педагогічних наук, доцент, дочент кафедри початкової та дошкільної освіти Львівського національного університету імені Івана Франка Неля Сірант, кандидат педагогічних наук, дочент кафедри початкової та дошкільної освіти Львівського національного університету імені Івана Франка Марта Проц, кандидат педагогічних наук, доцент кафедри початкової та дошкільної освіти Львівського національного університету імені Івана Франка

\title{
ЕСТЕТИЧНЕ ОЦІНЮВАННЯ ДІЯЛЬНОСТІ ЯК АКТУАЛЬНИЙ НАПРЯМ РОЗВИТКУ ЗДІБНОСТЕЙ У ДІТЕЙ
}

У статті підкреслено, щуо піднесення художнього сприймання у дітей здійснюється декількома шляхами це - розвиток естетичного сприймання, формування естетичних почуттів та розвиток здібності до інтерпретації картин, розуміння зображеного.

Особистісна орієнтачія сучасної освіти передбачає залучення дитини до естетичного досвіду людства, до творчої діяльності, до естетичного очінювання діяльності, яка виступає осередком естетичного розвитку індивіда. У взаємовідноченню з відповідним оиянюванням набуває сприйняття точних запитань естетичної вихованості та естетичної роботи, оцінювання естетичної діяльності та опорних теоретичних засад створення естетичної очінки дитини.

Ключові слова: естетичне оцінювання; естетичні смаки; дитина; естетичне ставлення.

Jim. 6.

Svitlana Lozynska, Ph.D.(Pedagogy), Associate Professor, Associate Professor of the Primary and Preschool Education Department Ivan Franko National University of Lviv Nelya Sirant, Ph.D.(Pedagogy), Associate Professor of the Primary and Preschool Education Department Ivan Franko National University of Lviv Marta Prots, Ph.D.(Pedagogy), Associate Professor of the Primary and Preschool Education Department Ivan Franko National University of Lviv

\section{AESTHETIC ASSESSMENT OF ACTIVITY, A PROMISING PATH IN CHILDREN'S SKILL DEVELOPMENT}

As described in the paper, the children's artistic perception evolves along several pathways - developing aesthetic perception and taste, and building on skills to interpret works of art, understand and assess them.

The individual-oriented education of modern times envisions the child's involvement into community's aesthetic practices, creative work and aesthetic assessment of activity that is in the core of a person's aesthetic development. These are closely interrelated with the perception of specific questions of aesthetic schooling and activity, as well as assessment of such activity and theoretical basis of a child's aesthetic assessment.

Aesthetic assessment is defined as a person's successful correlation between a given object or image and established aesthetic standards or etalons. It relates to categories of wonderful vs. disgusting, marvelous vs. repulsive, horrible vs. amusing in reality around us and in works of art.

The child's perception of beauty, basic aesthetic taste and the ability to understand and assess the world around must be developed from an early age; and in order to understand, a child has to get accustomed to experiencing beautiful things. The basic criteria of aesthetic assessment for children are related to the perception of taste and include color, shape, etc. A child perceives the shapes and color palettes in each work of art not only by the sense or impression they were intended for, but also by his or her personal taste, which prompts to give preference to some objects or things before the others. A child is therefore extraordinarily active, trying to examine and assess everything in all aspects and in his or her own way, to express an opinion and assessment. Thus, in the course of development of artistic perception, the basic skills of aesthetic assessment of the surrounding reality emerge. Naturally, the children's assessment is relatively elementary, but they evolve into meaningful perception when children learn to identify the basic features of expression (such as composition, shape, colors and their combination, etc.)

To shape and develop the skill of aesthetic assessment, teachers should be oriented at the best examples, capable of suggestion, and present a standard of aesthetically educated person themselves.

Keywords: aesthetic assessment; aesthetic taste; child; aesthetic attitude.

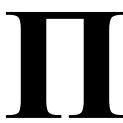

остановка проблеми. Естетичне виховання - це процес формування естетичного ставлення людини до

світу. Останнє є складним і водночас цілісним утворенням, до структури якого входить естетичне сприймання, процес оцінювання, 


\section{ЕСТЕТИЧНЕ ОЦНЮВАННЯ ДІЯЛЬНОСТІ ЯК АКТУАЛЬНИЙ НАПРЯМ РОЗВИТКУ ЗДІБНОСТЕЙУ ДІТЕЙ}

естетична діяльність. В естетичному розумінні важливий кожен з названих компонентів. Водночас варто особливо підкреслити значення процесу оцінювання.

Аналіз основних досліджень і публікацій. У наукових роботах деяких учених підкреслюються суцільні питання естетичної вихованості дитини (О. Абдулліна, А. Верхова, А. Шевченко, Г. Нагорна, Р. Хмелюк, О. Цокур). Розглянуто своєрідність ходу групування естетичної особистості дитини в умовах закладу освіти (Е. Карпова, Н. Кічук, В. Сластьонін); естетичної культури (Л. Гарбузенко, С. Гармаш, П. Кравчук, С. Мельничук). Питання піднесення індивіда, його творчих задатків у вчених завше була на першому місці вчених. Психологічні основи розвитку досліджували Л. Божович, Л. Виготський, В. Давидов, Г. Костюк, О. Леонтьєв, Н. Тализіна та ін., педагогічний план зазначеного питання аналізували В. Андрєєв, О. Савченко, М. Скаткін, Т. Шамова та ін.

Мета статті - дослідити теоретичні аспекти естетичного оцінювання на розвиток здібностей у дітей.

Виклад основного матеріалу. Естетичне ставлення - оцінне за своєю природою. У процесі різноманітної діяльності у людей формується естетична потреба в удосконаленні всього життєвого середовища. Вона спрямовує людину на пошук предметів, які можуть їі задовольнити, - все сприйняте оцінюється 3 погляду цієї здатності. У механізмі естетичної оцінки визначальним є смак. Він виробляється завдяки аналітико-синтетичній діяльності мислення, обміну досвідом між людьми як сукупність естетичних норм, еталонів, тобто уявлень про те, якими мають бути предмети для естетичної потреби. Якість смаку в кожної людини залежить від того, наскільки розвинене у неї вміння виробляти, поглиблювати, розширювати ці мірила досконалості, наскільки правдиво вони відбивають сучасні потреби суспільства.

Процес оцінювання здійснюється шляхом співвідношення сприйнятого предмета з нормами, ідеалами. Залежно від ступеня їх збіжності визначається ступінь естетичної цінності предмета. Інформація про цінність предмета виявляється передусім у відповідному (позитивному чи негативному) емоційному ставленні до оцінюваного, тобто в естетичному почутті різної сили.

Смакова оцінка виявляється і в оцінних судженнях: найзагальнішим і більш конкретним, з обгрунтуванням, чому предмет подобається, здається красивим. В останньому випадку певною мірою усвідомлюється і те, що оцінюється, і за допомогою яких критеріїв здійснюється оцінювання. У цьому розумінні оцінка, особлива мотиваційна, - важливий показник рівня естетичної свідомості людини.

3'ясовуючи естетичну думку учнів 3 приводу того чи того явища, педагог має змогу цілеспрямовано впливати на їхні смаки внаслідок перебудови мотивації оцінок. Адже в процесі оцінної діяльності, суперечок не тільки усвідомлюються норми, критерії, які є в дитини, а й активнішим стає процес логічної і практичної перевірки засвоєння естетичних знань, поступове перетворення їх на особистий досвід, переконання [1, 109-116].

Проте значення естетичної оцінки полягає не тільки в цьому. Вимога щось оцінити, обговорити, активізує процес естетичного сприймання, бо змушує щось виділити у сприйнятому для зіставлення 3 нормою, придивлятися і виправляти естетичне сприйняття.

Естетична оцінка $\epsilon$ також стимулом, збуджувальним мотивом до діяльності за законами краси: людина прагне змінити те, що не дало їй позитивних переконань. У процесі ж самої естетичної творчості, перетворення предметів оцінювання результатів на окремих етапах виконує функцію коригування діяльності, спрямовуючи іiі до ідеалів.

На жаль, педагоги не завжди розуміють значення організації активної оцінної діяльності дітей для естетичного виховання, тож не приділяють їй належної уваги. Частина педагогів уважають, що осягнення краси відбувається тільки інтуїтивно, саме собою, тому не потребує спеціальної роботи. С і такі, що піднімають самостійну оцінку діяльності дітей власними оцінками без аргументів. (Діти, сьогодні літо подарувало нам чудовий день. Подивіться навколо, яка краса!) [5].

Щодо оцінювання творів мистецтва побутує думка, ніби дітям ще зарано починати роботу над формуванням художньо-естетичних оцінок: хай вони просто читають, сприймають, нагромаджують матеріали. 3 часом можна вже серйозно займатися розвитком їх здатності оцінювати. Виходить, що малеча починає вивчати твір не тільки для засвоєння змісту, а й для того, щоб за його допомогою виховувати ставлення до життя, формування особистості. Не враховується й те, що естетичне ставлення формується не поетапно: спочатку, мовляв, навчись сприймати правильно, а вже потім оцінюй, переживай. Оцінюється на різному рівні усвідомленості все сприйняте, незалежно від того, правильне чи неправильне це сприймання, стимулюємо його чи ні. Так, до 135 


\section{ЕСТЕТИЧНЕ ОЦІНЮВАННЯ ДІЯЛЬНОСТІ ЯК АКТУАЛЬНИЙ НАПРЯМ РОЗВИТКУ ЗДІБНОСТЕЙУ ДІТЕЙ}

оповідань і віршів у Читанці для малят дано понад 30 запитань і завдань. Однак більшість 3 них допомагає розкриттю змісту, деякі сприяють виявленню художніх особливостей творів.

Методичні рекомендації та розробки з аналізу мистецтва часто рясніють висловами “видатне полотно”, “велике творіння”, “надзвичайна майстерність”, проте не орієнтують педагога на їх аргументування. Такий метод нав'язування оцінок не зачіпає і не перебудовує дитячих уявлень про красу, про художню майстерність, хіба що привчає до фразерства.

Ігнорування оцінної діяльності дітей неминуче перетворює заходи 3 художньо-естетичного виховання на формальні, пасивні і бездійові, не дає змоги використати весь навчально-виховний потенціал мистецтва [2].

Щоб допомогти дитині швидше навчитись правильно сприймати, засвоїти доступні ії рівню суспільно значущі критерії прекрасного і виробити відповідні оцінки, естетично-оцінний підхід до всього, розвитком здатностей до оцінної діяльності треба займатися не епізодично, - ним має бути пройнятий кожен елемент будь-якої роботи, і проводити її слід у певній системі.

Зупинимось на деяких моментах оцінювання художніх творів і різних видів дитячої творчості.

Як уже зазначалось, оцінювання здійснюється на основі певних критеріїв підходу до явищ дійсності, до мистецтва. Тому перше, з чого має почати педагог, - озброїти дитину чіткими, глибоко усвідомленими критеріями досконалості.

У читанні художніх творів, віршів передує складання усних творів за малюнком. Цей поданий вид роботи надзвичайно важливий, оскільки він сприяє розвитку в дітей цілого комплексу здібностей - спостережливості, уявлення, мислення, мови, творчості. Діти слухають оповідання своїх друзів - доступні, зрозумілі не тільки за змістом, а й за формою. Отже, їм легше оцінити дитячу розповідь, ніж, скажімо, твори письменників. Уже з перших днів навчання діти виділяють тих, хто вміє розповідати цікаво, зрозуміло, і тих, хто “плутається”. Усе це - сприятливий грунт для того, щоб поступово перевести інтуїтивний підхід дітей в усвідомлений.

У досконалому оповіданні діти мають констатувати відповідність змісту назві, зв'язність, послідовність, чіткість, цілісність, точність, ясність, повноту, цікавість його, художність [4, 46-52].

Безперечно, в абстрактному, теоретичному вигляді дітям заважко сприйняти ці критерії, та досвід свідчить, що вони легко засвоюють і усвідомлюють, якщо подати їх у доступній формі, образною мовою.
Діти розглядають малюнки і за чергою розповідають, що вони бачать на малюнку, доповнюючи розповіді один одного. Вислухавши ці розповіді, педагог сам передає зміст малюнка. Дітям пропонують з'ясувати, чим ця розповідь відрізняється від попередньої, на що вона схожа. 3 багатьох висловлювань педагог виділяє спочатку такі:

- Ви пов'язали все разом?

- Ніби зібрали букет.

Педагог узагальнює: ваші розповіді, схожі на букет, на з'єднані разом вагони, літери у слові, згодом звертає увагу дітей на свою розповідь: вона змістовна, отже, цікава.

Для закріплення пропонується розглянути інший малюнок і колективно скласти зв'язне, послідовне, повне оповідання.

На наступних заняттях доцільно пояснити дітям, що в оповіданні зміст має відповідати назві, бути пройнятим головною думкою, логічно завершеним [3].

На одному із занять педагог ставить за мету підкреслити дітям важливість для оповідання цілісності та закінченості, дібравши для оцінювання два оповідання за тією самою картиною. На наступних заняттях педагогу слід заохочувати здобувачів, відзначати точно знайдене слово, вислів, радіти власному образу. Поступово вони привчають говорити так, щоб сподобалося педагогу, друзям. Запам'ятовують найбільш вдалі образи, вводять їх у свої розповіді. 3 часом варто спеціально поговорити про критерії точності, ясності мови, її яскравості. Найкраща нагода для цього - якщо в когось 3 дітей вийде справді цікавий твір.

Зазвичай зміст вимог дещо змінюється залежно від типу оповідання, його жанру та інших особливостей. Скажімо, критерій точності стосовно розповіді за малюнком. Якщо ж говорити про переказ твору, то має йтися не тільки про точний опис фактів, а й про те, щоб передати характер, тональність твору, а також настрій, почуття, які пережив письменник і хоче викликати у читача.

До такої діяльності педагог поступово залучає дітей, всіляко заохочуючи їх описувати свої почуття 3 приводу побаченого, привносити “особливий момент” у будь-яку розповідь. У дітей у жодному разі не повинно сформуватися уявлення, ніби розуміння мистецтва вичерпується фіксацією безпосередніх фактів. Інакше 3 набуттям навички порівняно легко і швидко визначати загальний зміст твору, його мету діти можуть втратити інтерес до мистецтва. Цього не станеться, якщо поглиблювати цю роботу, 


\section{ЕСТЕТИЧНЕ ОЦННЮВАННЯ ДІЯЛЬНОСТІ ЯКАКТУАЛЬНИЙ НАПРЯМ РОЗВИТКУ ЗДІБНОСТЕЙУ ДІТЕЙ}

розвивати і збагачувати раніше засвоєнні дітьми критерії досконалості.

У подальшому для розвитку оцінної діяльності педагоги використовують не тільки заняття, а й різноманітні види роботи: колективно оцінюють i відбираються на виставку та для вміщення у книгу-саморобку кращі роботи; діти обговорюють успіхи і невдачі своїх виступів на святах тощо. Педагог звертає увагу і на форму висловлення оцінки. Слід говорити спокійно, доброзичливо, не тільки критикувати, перелічувати зауваження, а й порадити, як краще зробити. Педагог навчає дітей такту в оцінюванні, вміння враховувати індивідуальні особливості друзів, уважно ставитися до кожного. Наприклад: “Матвійко довго хворів, відстав, йому важко вчитися, але подивіться: сьогодні в нього було кілька точних порівнянь..." [6].

Увага до художньо-естетичних засобів мистецтва, постійне зіставлення думок стимулюють уміння дітей логічно міркувати, обстоювати свої погляди, прагнути до самостійного добування істини. Завдяки цьому діти виявляються здатними до кінця навчання добре розуміти художні твори. Щоб правильно оцінити твір, потрібно вловити його зміст, втілити власне ставлення до сприйнятого у виразності читання педагога.

I чую тишу. І співають птиці.

Проходять люди гарні і незлі.

В пахучій хмарі дощової глиці

стоїть туман, як небо на землі. (Л.Костенко)

Усі уважно слухають вірш, після кількох хвилин роздуму діти розповідають про образи, які виникли у їхній уяві.

- Я бачу хмари. Чую спів пташок, бачу людей.

Подібно до цього дітки усно малюють ілюстрації до решти віршів прочитаних педагогом.

Ще однією оцінкою естетичних смаків виступає поезія, яку читає педагог дітям. Після прочитаного, учитель звертає увагу що поезію не слід читати як: ритмічне похитування вірша, одноманітне читання, а виділяти слова, що стимулюють настрій. Звертати увагу на яскраві моменти у вірші, які відтворюють настрій. Відзначають посилення сумного настрою: ні вогню, ні чорні хати, сумний світ. Останнє допомагає передати опис природи і ще більше підкреслює смуток, самотність, тугу. Вимальовується загальна картина: стоїть туман, як небо на землі.

Після обговорення поезії педагог пропонує діткам послухати іншу поезію, а згодом спільно оцінити іiі красу. Для поглиблення і закріплення оцінного ставлення до вірша, що виникло у дітей, можна використати музику.
- Діти, ми говоримо про мову вірша, чіткість, точність, образність слів, які допомогли поету передати свій настрій, навіяний літньою дорогою. А як ці почуття поета передати музикою, звуками? Що потрібно для цього композитору.

- Він має відчувати як поет.

- Композитор мусить любити цей вірш.

- Йому треба вміти споглядати картини, бачити цю погоду.

- Якою ви уявляєте музику про змальовані поетом картини?

- Звуки мають бути веселі.

Висновки. Отже, у ході сприймання складного об'єкта, котрим виступає композиція на картині, чітко проявляються діалектичні відношення частин і цілого, аналізу і синтезу, споглядання і мислення.

Для розуміння змісту малюнка, котрий сприймають, важливу роль відіграє його назва як типове формулювання головної ідеї картини (синтез). Назва змушує дитину знову до докладнішого ії розглядання (поглиблений аналіз). Така розумова діяльність забезпечує тривале збереження образу, що склався, і його подальше використання дітьми в різних видах практичної і художньої діяльності.

Свідома оцінна діяльність - своєрідний важіль розвитку усіх компонентів естетичного ставлення людини до світу. Розвиток здатності естетично оцінювати явища - обов'язкова умова формування усвідомленого естетичного ставлення. Систематично розвиваючи оцінну діяльність дітей, ми формуємо в них звичку все оцінювати, до всього виробляти усвідомлене особисте ставлення. А це, на наш погляд, - одна з важливих рис світогляду.

\section{ЛІТЕРАТУРА}

1.Везумська О. М. Естетичний розвиток учнів початкових класів. Таврійський вісник освіти, 2011. № 4 (36), C. 109-116.

2. Зданевич Л. Методика використання творів живопису як засобу розвитку зв'язного мовлення дітей старшого дошкільного віку. Дошкільна освіта. 2008 (3).

3. Калашник Н.Г. Естетичні смаки: їх витоки i формування. Запоріжжя, 2001.

4. Муха О.Я. Естетичний смак в динаміці розвитку: структурно-факторний аналіз. Вісник Дніпропетровського університету. 2012.9/2. C.46-52.

5. Пархоменко О. М. Виховання гуманістичної спрямованої особистості у позаурочний час. Черкас. ЦНТЕI, 2005. $144 \mathrm{c}$.

6. Соколова Алла. Естетичний смак як наукова проблема. URL: http://dspace.hnpu.edu.ua/bitstream/ $123456789 / 4311 / 1 / \% \mathrm{D} 0 \% \mathrm{~A} 1 \% \mathrm{D} 0 \% \mathrm{BE} \% \mathrm{D} 0 \% \mathrm{BA} \% \mathrm{D} 0$ \%BE\%D0\%BB\%D0\%B E\%D0\%B2\%D0\%B $\%$ 20\%D0\%90.\%20\%D0 \%92.\%20\%D0\%95\%D1\% 


\section{ВІДОБРАЖЕННЯ РЕЛІГІЙНИХ ТА ІСТОРИЧНИХМОТИВІВ}

В УКРАЇНСЬКІЙ ДУХОВНІЙ ПІСНІ ХVII-ХVIII СТ.

81\%D1\%82\%D0\%B5\%D1\%82\% D0\%B8\%D1\%87\%D $\begin{array}{lllllllllllllllllll}0 & \% & \mathrm{~B} & \mathrm{D} & \% & \mathrm{D} & 0 & \% & \mathrm{~B} & 8 & \% & \mathrm{D} & 0 & \% & \mathrm{~B} & 9 & \% & 2 & 0\end{array}$ $\% \mathrm{D} 1 \% 81 \% \mathrm{D} 0 \% \mathrm{BC} \% \mathrm{D} 0 \% \mathrm{~B} 0 \% \mathrm{D} 0 \% \mathrm{BA} . \mathrm{pdf}$ (дата звернення 29.05.2021).

\section{REFERENCES}

1.Vezumska, O. M. (2011). Estetychnyi rozvytok uchniv pochatkovykh klasiv [Aesthetic development of primary school students]. Taurian Bulletin of Education. No. 4 (36), pp.109-116. [in Ukrainian].

2. Zdanevych, L. (2008). Metodyka vykorystannia tvoriv zhyvopysu yak zasobu rozvytku zviaznoho movlennia ditei starshoho doshkilnoho viku [Methods of using paintings as a means of developing coherent speech of older preschool children]. Pre-school education. No. 3. [in Ukrainian].

3. Kalashnyk N.H. (2001). Estetychni smaky: yikh vytoky i formuvannia [Aesthetic tastes: their origins and formation]. Zaporizhzhia. [in Ukrainian].
4. Mukha, O.Ia. (2012). Estetychnyi smak v dynamitsi rozvytku: strukturno-faktornyi analiz [Aesthetic taste in the dynamics of development: structural-factor analysis] Bulletin of Dnipropetrovsk University. No. 9/2 . pp.46-52. [in Ukrainian].

5.Parkhomenko, O. M. (2005). Vykhovannia humanistychnoi spriamovanoi osobystosti u pozaurochnyi chas [Education of a humanistic personality in extracurricular activities]. Cherkasy, p.144. [in Ukrainian].

6. Sokolova, Alla. Estetychnyi smak yak naukova problema [Aesthetic taste as a scientific problem]. Available at: http://dspace.hnpu.edu.ua/bitstream/ $123456789 / 4311 / 1 / \%$ D0 \%A 1\%D0\%BE\%D0\% B A $\%$ D $0 \%$ B E $\%$ D $0 \%$ B B $\%$ D $0 \%$ B $\mathrm{E} \% \mathrm{D} 0 \% \mathrm{~B} 2 \% \mathrm{D} 0 \% \mathrm{~B} 0 \% 20 \% \mathrm{D} 0 \% 90$. $\% 20 \% \mathrm{D} 0 \% 92 \% 20 \% \mathrm{D} 0 \% 95 \% \mathrm{Dl} \% 81 \% \mathrm{Dl} \% 82 \% \mathrm{D} 0 \% \mathrm{~B} 5 \% \mathrm{Dl} \% 82 \%$ D $0 \%$ B $8 \%$ D $1 \% 87 \%$ D $0 \%$ B D \% D $0 \%$ B 8 $\% \mathrm{D} 0 \% \mathrm{~B} 9 \% 20 \% \mathrm{D} 1 \% 81 \% \mathrm{D} 0 \% \mathrm{BC} \% \mathrm{D} 0 \% \mathrm{~B} 0 \% \mathrm{D} 0 \% \mathrm{BA} . \mathrm{pdf}$ (Accessed 29 May 2021). [in Ukrainian].

Стаття надійшла до редакції 26.04.2021

УДК 371.2:378

DOI:

Галина Медведик, старший викладач кафедри музикознавства та фортепіано Дрогобицького державного педагогічного університету імені Івана Франка

\section{ВІДОБРАЖЕННЯ РЕЛІГІЙНИХ ТА ІСТОРИЧНИХ МОТИВІВ В УКРАЇНСЬКІЙ ДУХОВНІЙ ПІСНІ ХVII-XVIII СТ.}

У статті розглянуто окремі аспекти змісту українських духовних пісень XVII-XVIII ст. Виявлено, що в окремих піснях поєднуються релігійні та історичні мотиви, спрямовані на відображення суспільних потреб поруч із традиційними молитовними зворотами. Підкреслено роль духовної пісні у педагогічно-виховному контексті, що особливо важливо в контексті тяглості музично-поетичних текстів від бароко до середньовіччя. Відтак проведено аналіз вибраних пісень, який свідчить про лексичні паралелі гимнографічних піснеспівів і духовних пісень. Підкреслено тяглість і актуальність в барокову добу півчої літургійної практики. Це зумовило поєднання в українській культурі традичій обрядових богослужінь $і$ західноєвропейський католицько-протестантський досвід духовного співу. В такий спосіб увиразнено і обтрунтовано вагомість української духовної пісні в мистецькій начіональній скарбниці.

Ключові слова: українська духовна пісня; гимнографія; Богородиия; архангел Михайл; Богогласник.

Jim. 14.

Halyna Medvedyk, Senior Lecturer of the Musicology and Piano Department of the Drohobych Ivan Franko State Pedagogical University

\section{REPRESENTATION OF RELIGIOUS AND HISTORICAL MOTIVES IN THE UKRAINIAN SPIRITUAL SONGS OF THE 17-18 ${ }^{\mathrm{TH}}$ CENTURIES}

Over the centuries, genres and forms that highlight society's fundamental problems and needs have been developed in the Ukrainian culture. The prolonged absence of independence and difficult political circumstances in the life of the Ukrainian ethnic group led to the distinction of national and patriotic themes in various artistic manifestations. This is especially evident in folk songs and legends, which are well remembered and most quickly passed on in oral practice. With the development of musical art, the spiritual song also developed.

The process of inception and development of spiritual songs in Ukrainian culture was long-lasting. The most powerful stage fell on the Baroque era; however, even after the decades of Romanticism, the spiritual music remained an essential component of Ukrainians' national religious and musical culture. This was probably due to the intimacy of the form to the ordinary folk songs and the current content, which reflected the pressing problems of society, the most important historical events, and liturgical holidays or Christian symbols.

Therefore, the article deals with some aspects of the content of Ukrainian spiritual songs of the 17-18 ${ }^{\text {th }}$ centuries. For the analysis were selected such songs: spiritual songs "Zlyi Tataryne" ("Evil Tatar"), written not 